Dhaka Univ. J. Biol. Sci. 23(2): 173-178, 2014 (July)

\title{
PERFORMANCE OF AN ORGANIC FERTILIZER ON THE GROWTH AND YIELD OF RICE
}

\author{
M.A. AzIZ1 ${ }^{1}$ M.S. HossAin ${ }^{1}$ and M.J. UdDiN* \\ Department of Soil, Water and Environment, University of Dhaka, \\ Dhaka-1000, Bangladesh
}

Key words: Organic fertilizer, Growth and yield, Rice

\begin{abstract}
A total of 9 treatments of Northern Jaibo-Sar (NJS) and Northern Bio Fertilizer (NBF) in combination with different proportions of soil test based fertilizer (SBF) together with a control was applied, Northern Shakti was used instead of NBF in Boro season. Maximum net benefit and marginal rate of return was obtained in case of T. Aman and Boro season from treatment $\mathrm{T}_{3}$. On the basis of results, it may be suggested that $50 \%$ reduction of chemical fertilizer on STB along with Northern Jaibo-Sar @ 500kg/ha may be a good combination of organic and inorganic fertilizer for sustaining soil fertility and increasing T. Aman and Boro rice.
\end{abstract}

\section{Introduction}

Continuous use of inorganic fertilizers alone to soils had a deleterious effect on soil productivity and in rice productivity(1). Organic matter content of the soils is constantly lessening by repeated farming which leads to hard soil. Nutrient rich organic fertilizer improves soil condition; reduce soil compactness, clotting and erosion. Suitable organic sources of nutrients are necessary for sustainable agriculture that will provide maximum rice production with good quality and maintain a sound environment. Organic matter is the vital component of soil health as well as crop production. Most of the cultivated soil in Bangladesh, organic matter is very low ranging from $0.5-2 \%$ where majority of the cultivated soils is less than $1 \%{ }^{(2)}$. Northern Jaibo-Sar is a nutrient enriched organic fertilizer containing total N (4\%), P (1.15\%), K (1.5\%), S (1\%) and some trace element ${ }^{(3)}$. Hence, the performance of this fertilizer was evaluated in the farmer's field in T. Aman, 2011 and Boro rice, 2012 seasons.

\section{Materials and Methods}

Two experiments were conducted at farmer's field, Tukerbazar, Sylhet during T. Aman season, 2011 and Boro season, 2012. The initial soil properties of the experimental site is presented in Table 1 . Soil texture, $\mathrm{pH}$, organic matter, available $\mathrm{P}, \mathrm{S}, \mathrm{Zn}$ and

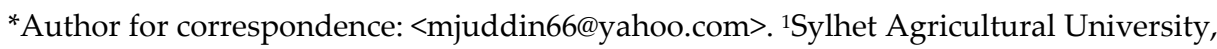
Sylhet-3100, Bangladesh. 
exchangeable $\mathrm{K}$ were determined following standard methods ${ }^{(4-8)}$. The elemental composition of Northern Bio Fertilizer (NBF) was $\mathrm{N}=6.48 \%, \mathrm{P}=4.56 \%, \mathrm{~K}=1.2 \%, \mathrm{~S}=$ $3.36 \%, \mathrm{Zn}=0.40 \%$, and $\mathrm{B}=0.10 \%$ where as in Northern Shakti, $\mathrm{N}=6.0 \%, \mathrm{P}=3.5 \%, \mathrm{~K}=$ $8.5 \%, \mathrm{~S}=2 \%, \mathrm{Ca}=2 \%, \mathrm{Mg}=1 \%$ and $\mathrm{B}=0.10 \%$. The following nine treatment combinations were tested in T. Aman season : $\mathrm{T}_{1}=$ Control, $\mathrm{T}_{2}=$ Northern Jaibo-Sar (NJS) @ $500 \mathrm{~kg} / \mathrm{ha}, \mathrm{T}_{3}=\mathrm{STB}$ (Soil Test Based), $\mathrm{T}_{4}=\mathrm{T}_{2}+\mathrm{NBF} @ 250 \mathrm{~kg} / \mathrm{ha}+$ Recom. N, $\mathrm{T}_{5}=\mathrm{T}_{2}+$ $50 \% \mathrm{STB}, \mathrm{T}_{6}=\mathrm{T}_{2}+60 \% \mathrm{STB}, \mathrm{T}_{7}=\mathrm{T}_{2}+70 \% \mathrm{STB}, \mathrm{T}_{8}=\mathrm{T}_{2}+80 \% \mathrm{STB}$ and $\mathrm{T}_{9}=\mathrm{T}_{2}+\mathrm{T}_{3}$. The experiment was laid out in a RCBD with three replications having unit plot size of $6 \mathrm{~m} \times$ $5 \mathrm{~m}$. Fertilizer doses on STB were $77 \mathrm{~kg} \mathrm{~N}, 18 \mathrm{~kg} \mathrm{P}, 36 \mathrm{~kg} \mathrm{~K}$ and $13 \mathrm{~kg} \mathrm{~S} / \mathrm{ha}$ and was applied as urea, TSP, MP and gypsum, respectively. BRRIdhan 31 was used as test crop. Thirty-day-old 2 - 3 seedling/hill were transplanted with $20 \mathrm{~cm} \times 20 \mathrm{~cm}$ spacing. During Boro season, the same nine treatment combinations were tested except treatment $\mathrm{T}_{4}$. The treatment $\mathrm{T}_{4}$ was as NJS @ $500 \mathrm{~kg} / \mathrm{ha}+$ Northern Shakti @ $500 \mathrm{~kg} / \mathrm{ha}+$ Recom. N. Fertilizer doses on STB were $115 \mathrm{~kg} \mathrm{~N}, 30 \mathrm{~kg} \mathrm{P,} 56 \mathrm{~kg} \mathrm{~K}$ and $23 \mathrm{~kg}$ S/ha and was applied as urea, TSP, MP and gypsum, respectively. BRRIdhan 29 was used as test crop. Fifty day old 2-3 seedling/hill were transplanted with $20 \mathrm{~cm} \times 20 \mathrm{~cm}$ spacing. TSP, MP, Gypsum and Northern Jaibo-Sar were applied at final land preparation. Urea was applied into three equal splits, $1 / 3$ basal, $1 / 3$ rd maximum tillering stage and the remaining

Table 1. Initial soil properties of the experimental site of farmer's field of Tukerbazar, Sylhet.

\begin{tabular}{lc}
\hline Soil properties & Results \\
\hline Texture & Clay loam \\
pH $(1: 2.5)$ & 5.42 \\
Total N (\%) & 0.13 \\
P (ppm) & 6.04 \\
K (meq/100g soil) & 0.15 \\
S (ppm) & 6.78 \\
Zn (ppm) & 2.1 \\
\hline
\end{tabular}

$1 / 3$ rd at panicle initiation stage. Necessary intercultural operations were done as and when required. At maturity, the crop was harvested from $5 \mathrm{~m}^{2}$ area for grain and straw yield and grain yield was adjusted to $14 \%$ moisture content. The plant height, tiller, panicle production, grain and straw yield were recorded. Finally economic analyses were done for net benefit and marginal rate of return.

\section{Results and Discussion}

Application of chemical fertilizer on Soil Test Based (STB) alone or in combination with Northern Jaibo-Sar (NJS) in T. Aman increased the plant height, tiller and panicle number of rice significantly over the control. Highest plant height and maximum number of tiller and panicle was recorded in treatment $\mathrm{T}_{9}$ followed by $\mathrm{T}_{3}$. Maximum 1000-grain 
weight was found in the $\mathrm{T}_{8}$ followed by $\mathrm{T}_{2}$ (Table 2). Chemical fertilization alone or in combination with NJS produced identical and substantially higher grain and straw yield of rice than those of control and lone application of NJS.

Table 2. Effect of Northern Jaibo-Sar alone and in combination with chemical fertilizer on the growth and yield of T. Aman rice.

\begin{tabular}{ccccccc}
\hline Treatment* $^{*}$ & $\begin{array}{c}\text { Plant height } \\
(\mathrm{cm})\end{array}$ & $\begin{array}{c}\text { Tiller } \\
\text { No./m² }\end{array}$ & $\begin{array}{c}\text { Panicle } \\
\text { No./m² }\end{array}$ & $\begin{array}{c}\text { 1000-grain } \\
\text { wt. }(\mathrm{g})\end{array}$ & $\begin{array}{c}\text { Grain yield } \\
(\mathrm{t} / \mathrm{ha})^{* *}\end{array}$ & $\begin{array}{c}\text { Straw yield } \\
(\mathrm{t} / \mathrm{ha})\end{array}$ \\
\hline $\mathrm{T}_{1}$ & 104 & 160 & 139 & 26.4 & 2.84 & 3.61 \\
$\mathrm{~T}_{2}$ & 107 & 174 & 160 & 26.7 & 3.07 & 3.76 \\
$\mathrm{~T}_{3}$ & 117 & 223 & 203 & 26.4 & 3.59 & 5.09 \\
$\mathrm{~T}_{4}$ & 113 & 219 & 197 & 25.9 & 3.35 & 4.94 \\
$\mathrm{~T}_{5}$ & 114 & 211 & 195 & 25.9 & 3.57 & 5.03 \\
$\mathrm{~T}_{6}$ & 114 & 205 & 179 & 26.5 & 3.42 & 4.80 \\
$\mathrm{~T}_{7}$ & 114 & 221 & 196 & 25.5 & 3.62 & 4.92 \\
$\mathrm{~T}_{8}$ & 116 & 220 & 202 & 27.0 & 3.46 & 5.55 \\
$\mathrm{~T}_{9}$ & 120 & 229 & 205 & 26.4 & 3.46 & 4.78 \\
LSD (5\%) & 8 & 41 & 37 & 1.2 & 0.38 & 0.94 \\
\hline
\end{tabular}

${ }^{*} \mathrm{~T}_{1}=$ Control, $\mathrm{T}_{2}=$ Northern Jaibo-Sar (NJS) @ $500 \mathrm{~kg} / \mathrm{ha}, \mathrm{T}_{3}=\mathrm{STB}$ (Soil Test Based), $\mathrm{T}_{4}=\mathrm{T}_{2}+$ Northern BF@ 250 kg/ha + Recommended N, T5 $=\mathrm{T}_{2}+50 \% \mathrm{STB}, \mathrm{T}_{6}=\mathrm{T}_{2}+60 \% \mathrm{STB}, \mathrm{T}_{7}=\mathrm{T}_{2}+70 \% \mathrm{STB}$, $\mathrm{T}_{8}=\mathrm{T}_{2}+80 \%$ STB and $\mathrm{T}_{9}=\mathrm{T}_{2}+\mathrm{T}_{3} .{ }^{*}$ Yield reduced due to attack of tungro disease.

The treatment $\mathrm{T}_{7}$ produced maximum grain yield followed by $\mathrm{T}_{3}$ and $\mathrm{T}_{5}$. From the results it appeared that the integrated use of NJS @ $500 \mathrm{~kg} / \mathrm{ha}$ along with $30-50 \%$ reduced rate of chemical fertilizer may be sufficient to produce substantially higher yield of rice.

Application of chemical fertilizer on STB alone or in combination with NJS in Boro season increased the plant height, tiller and panicle number of rice over the control. Highest plant height and maximum number of tiller and panicle was recorded in $T_{4}$ followed by $\mathrm{T}_{9}$. Highest 1000 -grain weight was obtained in the $\mathrm{T}_{3}$ and $\mathrm{T}_{6}$ followed by $\mathrm{T}_{9}$ (Table 3). Chemical fertilization alone or in combination with NJS produced identical and substantially higher grain and straw yield of rice than those of control and lone application of NJS. The T9 produced maximum grain yield followed by $\mathrm{T}_{4}$. From the results it appeared that the integrated use of NJS @ $500 \mathrm{~kg} / \mathrm{ha}$ along with $30-50 \%$ reduced rate of chemical fertilizer may be sufficient to produce substantially higher yield of rice. Similar observation was shown when Moni Mukta organic fertilizer in combination with $50 \%$ of recommended dose of chemical fertilizer produced substantially higher yield than those of other tested treatments ${ }^{(9)}$. 
Economic analysis on partial budget of the experiment is presented in Tables 4 and 5. The net benefit of each treatment is calculated by subtracting the total costs that vary from the gross field benefit. The total costs that vary are the sum of all the costs that vary

Table 3. Effect of Northern Jaibo-Sar alone and in combination with chemical fertilizer on the growth and yield of boro rice.

\begin{tabular}{cccccccc}
\hline Treatment $^{*}$ & $\begin{array}{c}\text { Plant ht. } \\
(\mathrm{cm})\end{array}$ & $\begin{array}{c}\text { Tiller } \\
\text { No./m² }\end{array}$ & $\begin{array}{c}\text { Panicle } \\
\text { No./m² }\end{array}$ & $\begin{array}{c}\text { Sterility } \\
(\%)\end{array}$ & $\begin{array}{c}\text { 1000-grain } \\
\text { wt. }(\mathrm{g})\end{array}$ & $\begin{array}{c}\text { Grain } \\
\text { yield } \\
\text { (t/ha })\end{array}$ & $\begin{array}{c}\text { Straw } \\
\text { yield } \\
(\mathrm{t} / \mathrm{ha})\end{array}$ \\
\hline $\mathrm{T}_{1}$ & 80 & 174 & 168 & 11 & 22.5 & 2.96 & 3.54 \\
$\mathrm{~T}_{2}$ & 83 & 170 & 161 & 10 & 23.5 & 3.24 & 3.72 \\
$\mathrm{~T}_{3}$ & 97 & 239 & 229 & 11 & 24.4 & 5.99 & 6.2 \\
$\mathrm{~T}_{4}$ & 100 & 281 & 272 & 20 & 23.4 & 6.15 & 6.54 \\
$\mathrm{~T}_{5}$ & 91 & 230 & 222 & 10 & 23.6 & 5.13 & 5.49 \\
$\mathrm{~T}_{6}$ & 96 & 234 & 221 & 12 & 24.4 & 5.16 & 5.29 \\
$\mathrm{~T}_{7}$ & 95 & 210 & 199 & 9 & 23.6 & 5.52 & 5.62 \\
$\mathrm{~T}_{8}$ & 97 & 264 & 246 & 14 & 23.4 & 5.79 & 6.05 \\
$\mathrm{~T}_{9}$ & 99 & 270 & 260 & 9 & 23.7 & 6.19 & 6.32 \\
LSD (5\%) & 4 & 46 & 48 & 4 & 1.17 & 2.96 & 3.54 \\
\hline
\end{tabular}

${ }^{*} \mathrm{~T}_{1}=$ Control, $\mathrm{T}_{2}=$ Northern Jaibo-Sar (NJS) @ $500 \mathrm{~kg} / \mathrm{ha}, \mathrm{T}_{3}=\mathrm{STB}$ (Soil Test Based), $\mathrm{T}_{4}=\mathrm{T}_{2}+$ Northern Shakti @ $500 \mathrm{~kg} / \mathrm{ha}+$ rrecommended $\mathrm{N}, \mathrm{T}_{5}=\mathrm{T}_{2}+50 \% \mathrm{STB}, \mathrm{T}_{6}=\mathrm{T}_{2}+60 \% \mathrm{STB}, \mathrm{T}_{7}=\mathrm{T}_{2}+70 \% \mathrm{STB}, \mathrm{T}_{8}=\mathrm{T}_{2}+80 \% \mathrm{STB}$ and $\mathrm{T}_{9}$ $=\mathrm{T}_{2}+\mathrm{T}_{3}$.

Table 4. Partial budget for the experiment of Northern Jaibo-Sar for T. Aman rice production.

\begin{tabular}{lllllllllll}
\hline \multirow{2}{*}{ Particulars } & \multicolumn{10}{c}{ Treatments } \\
\cline { 2 - 11 } & $\mathrm{T}_{1}$ & $\mathrm{~T}_{2}$ & $\mathrm{~T}_{3}$ & $\mathrm{~T}_{4}$ & $\mathrm{~T}_{5}$ & $\mathrm{~T}_{6}$ & $\mathrm{~T}_{7}$ & $\mathrm{~T}_{8}$ & $\mathrm{~T}_{9}$ \\
\hline Grain yield (t/ha) & 2.84 & 3.07 & 3.59 & 3.35 & 3.57 & 3.42 & 3.62 & 3.46 & 3.46 \\
Straw yield (t/ha) & 3.61 & 3.76 & 5.09 & 4.94 & 5.03 & 4.8 & 4.92 & 5.55 & 4.78 \\
Adjusted grain yield (t/ha) & 2.56 & 2.76 & 3.23 & 3.02 & 3.21 & 3.08 & 3.26 & 3.11 & 3.11 \\
Adjusted straw yield (t/ha) & 3.25 & 3.38 & 4.58 & 4.45 & 4.53 & 4.32 & 4.43 & 5.00 & 4.30 \\
Gross field benefit, grain (Tk/ha) & 25560 & 27630 & 32310 & 30150 & 32130 & 30780 & 32580 & 31140 & 31140 \\
Gross field benefit, straw (Tk/ha) & 6498 & 6768 & 9162 & 8892 & 9054 & 8640 & 8856 & 9990 & 8604 \\
Total gross field benefit (Tk/ha) & 32058 & 34398 & 41472 & 39042 & 41184 & 39420 & 41436 & 41130 & 39744 \\
Total gross field cost (Tk/ha) & 0 & 3500 & 3286 & 7016 & 5143 & 5471 & 5800 & 6128 & 6786 \\
Net benefit (Tk/ha) & 32058 & 30898 & 38186 & 32026 & 36041 & 33949 & 35636 & 35002 & 32958 \\
\hline
\end{tabular}

Urea $=$ Tk. $20 / \mathrm{kg}, \mathrm{TSP}=\mathrm{Tk} .26 / \mathrm{kg}, \mathrm{MP}=\mathrm{Tk} .2 . / \mathrm{kg}$, gypsum $=\mathrm{Tk} .10 / \mathrm{kg}$, Northern Jaibo-Sar $=\mathrm{Tk} .10 / \mathrm{kg}$, Northern $\mathrm{BF}=\mathrm{Tk} .12 / \mathrm{kg}$, paddy $=\mathrm{Tk} .15 / \mathrm{kg}$ and straw $=\mathrm{Tk} .3 / \mathrm{kg}$, as the requirement of the model the grain and straw yield was adjustment @ 10\% reduced level and minimum rate of return =100\%. 
for a particular treatment. The maximum net benefit was achieved in $\mathrm{T}_{3}$ followed by $\mathrm{T}_{5}$ (T. Aman season). On the other hand, the highest net benefit was found in $\mathrm{T}_{3}$ followed by $\mathrm{T}_{4}$ (Boro season).

Table 5. Partial budget for the experiment of Northern Jaibo-Sar for Boro rice production.

\begin{tabular}{llllllllll}
\hline Particulars & \multicolumn{1}{c}{ Treatments } \\
\cline { 2 - 10 } & $\mathrm{T}_{1}$ & $\mathrm{~T}_{2}$ & $\mathrm{~T}_{3}$ & $\mathrm{~T}_{4}$ & $\mathrm{~T}_{5}$ & $\mathrm{~T}_{6}$ & $\mathrm{~T}_{7}$ & $\mathrm{~T}_{8}$ & $\mathrm{~T}_{9}$ \\
\hline Grain yield (t/ha) & 2.96 & 3.24 & 5.99 & 6.15 & 5.13 & 5.16 & 5.52 & 5.79 & 6.19 \\
Straw yield (t/ha) & 3.54 & 3.72 & 6.2 & 6.54 & 5.49 & 5.29 & 5.62 & 6.05 & 6.32 \\
Adjusted grain yield (t/ha) & 2.66 & 2.92 & 5.39 & 5.54 & 4.62 & 4.64 & 4.97 & 5.21 & 5.57 \\
Adjusted straw yield (t/ha) & 3.19 & 3.35 & 5.58 & 5.89 & 4.94 & 4.76 & 5.06 & 5.45 & 5.69 \\
$\begin{array}{l}\text { Gross field benefit, grain } \\
\text { (Tk./ha) }\end{array}$ & 26640 & 29160 & 53910 & 55350 & 46170 & 46440 & 49680 & 52110 & 55710 \\
Gross field benefit, straw & 6372 & 6696 & 11160 & 11772 & 9882 & 9522 & 10116 & 10890 & 11376 \\
(Tk./ha) & & & & & & & & & \\
Total gross field benefit & 33012 & 35856 & 65070 & 67122 & 56052 & 55962 & 59796 & 63000 & 67086 \\
(Tk./ha) & & & & & & & & & \\
Total gross field cost & 0 & 3500 & 6426 & 9518 & 6713 & 7356 & 7998 & 8641 & 9926 \\
(Tk./ha) & & & & & & & & & \\
Net benefit (Tk./ha) & 33012 & 32356 & 58644 & 57604 & 49339 & 48606 & 51798 & 54359 & 57160 \\
\hline
\end{tabular}

Table 6. Dominance and marginal analysis of Northern Jaibo-Sar for rice production.

\begin{tabular}{ccccccc}
\hline \multirow{2}{*}{ Treatments } & \multicolumn{2}{c}{$\begin{array}{c}\text { Variation of total costs } \\
\text { (Tk./ha) }\end{array}$} & \multicolumn{2}{c}{$\begin{array}{c}\text { Net benefit } \\
\text { (Tk./ha) }\end{array}$} & \multicolumn{2}{c}{$\begin{array}{c}\text { Marginal rate of return } \\
\text { (\%) }\end{array}$} \\
\cline { 2 - 7 } & T. Aman & Boro & T. Aman & Boro & T. Aman & Boro \\
\hline $\mathrm{T}_{1}$ & 0 & 0 & 32058 & 33012 & 186 & 898 \\
$\mathrm{~T}_{2}$ & 3500 & 3500 & $30898 \mathrm{D}$ & 32356 & & \\
$\mathrm{~T}_{3}$ & 3286 & 6426 & 38186 & 58644 & & \\
$\mathrm{~T}_{4}$ & 7016 & 9518 & $32026 \mathrm{D}$ & $57604 \mathrm{D}$ & & \\
$\mathrm{T}_{5}$ & 5143 & 6713 & $36041 \mathrm{D}$ & $49339 \mathrm{D}$ & & \\
$\mathrm{T}_{6}$ & 5471 & 7356 & $33949 \mathrm{D}$ & $48606 \mathrm{D}$ & & \\
$\mathrm{T}_{7}$ & 5800 & 7998 & $35636 \mathrm{D}$ & $51798 \mathrm{D}$ & & \\
$\mathrm{T}_{8}$ & 6128 & 8641 & $35002 \mathrm{D}$ & $54359 \mathrm{D}$ & & \\
$\mathrm{T}_{9}$ & 6786 & 9926 & 32958D & 57160 D & & \\
\hline
\end{tabular}

$\mathrm{D}=$ Dominated; ${ }^{*} \mathrm{~T}_{1}=$ Control, $\mathrm{T}_{2}=$ Northern Jaibo-Sar (NJS) @ $500 \mathrm{~kg} / \mathrm{ha}, \mathrm{T}_{3}=\mathrm{STB}$ (Soil Test Based), $\mathrm{T}_{4}=\mathrm{T}_{2}+$ Northern BF@ $250 \mathrm{~kg} / \mathrm{ha}+$ recommended N, $\mathrm{T}_{5}=\mathrm{T}_{2}+50 \% \mathrm{STB}, \mathrm{T}_{6}=\mathrm{T}_{2}+60 \% \mathrm{STB}, \mathrm{T}_{7}=\mathrm{T}_{2}+70 \% \mathrm{STB}, \mathrm{T}_{8}=\mathrm{T}_{2}+$ $80 \%$ STB and $\mathrm{T}_{9}=\mathrm{T}_{2}+\mathrm{T}_{3}$.

In the experiment, the marginal rate of return between $\mathrm{T}_{1}$ and $\mathrm{T}_{3}$ was $186 \%$ (T. Aman season) and in $\mathrm{T}_{2}$ and $\mathrm{T}_{3}$ was $898 \%$ (Boro season) well above the $100 \%$ minimum. Farmers 
will continue to invest as long as the returns to each extra unit invested (measured by MRR) which were higher than the cost of the extra invested (Table 6). Thus, T3 (T. Aman season) and $T_{2}$ (Boro season) were the most economically viable treatments of the experiment.

In terms of economic point of view, the treatment $\mathrm{T}_{3}(\mathrm{STB})$ was found superior though the treatments $T_{5}$ and $T_{7}$ produced higher yield than that of the treatment $T_{3}$ (STB) (T. Aman season) and $\mathrm{T}_{2}$ (NJS @ $500 \mathrm{~kg} / \mathrm{ha}$ ) was found superior though the treatments $\mathrm{T}_{9}$ and $\mathrm{T}_{4}$ produced higher yield than that of the treatment $\mathrm{T}_{2}$. Integrated use of organic and inorganic fertilizer is the need of time for sustainable increased crop production and improved soil fertility. In addition, reduced use of chemical fertilizer positively influences the environment through reducing contamination of air, soil and water. Considering these points it may be suggested that $50 \%$ reduction of chemical fertilizer on STB along with Northern Jaibo-Sar @ 500kg/ha may be a good combination of organic and inorganic fertilizer for sustaining soil fertility and increasing T. Aman and Boro rice.

\section{References}

1. Nambiar KKM 1998. Major cropping system in India. In: Agricultural Sustainability: Economics Environmental and Statistical Considerations (Eds. Barmett et al.). John Wiley \& Sons, Chichester, UK. pp. 133-139.

2. Bangladesh Agricultural Research Council (BARC) 2001. Impact of land degradation in Bangladesh: Changing scenario of agricultural land use. Soils publication No. 42. Bangladesh Agricultural Research Council, Dhaka. pp. 32.

3. Northern Agro-Services Ltd. 1992. A world class fertilizer manufacturer company, Bangladesh. Govt. approved and DAE Reg. No. M-65. (www.northernfertilizer.org).

4. Black CA 1965. Methods of Soil Analysis. Part I and II. Amer. Soc. Agron. Inc. Pub., Madison. USA.

5. Jackson ML 1962. Soil Chemical Analysis. Prentice Hall of India. Pvt. Ltd., New Delhi. pp. 930.

6. Walkley A and AI Black 1934. An examination of the Degtjareff method for determining soil organic matter and a proposed modification of the chromic acid titration method. Soil Sci. 37: 29-38.

7. Olsen SR, CV Cole, FS Watanable and LA Dean 1954. Estimation of available phosphorus in soils by extraction with sodium carbonate U.S. Dept. Agr. (Circ.) pp. 929.

8. Page AL, RH Miller and DR Keeney 1982. Methods of Soil Analysis. Part 2. $2^{\text {nd }}$ Ed. Amer. Soc. Agron. Madison. Wisconsin, USA. pp. 622.

9. Aziz MA and MA Mazid Miah 2004. Performance of Moni Mukta organic fertilizer on the growth and yield of rice. J. Sub. Trop. Agric. Res. Dev. 2(1): 48-52. 